Archives of Agriculture and Environmental Science

\title{
Analysis of environmental damage and environmental economic valuation on tropical rain forest destruction in Simalungun Regency, North Sumatera Province, Indonesia
}

\author{
Basuki Wasis $^{1^{*}}$ (D) , Bambang Hero Saharjo ${ }^{1}$, Muhammad Hafiz Wasis Putra ${ }^{2}$ and Bayu Winata ${ }^{1}$ \\ ${ }^{1}$ Department of Silviculture, Faculty of Forestry, IPB University. Darmaga, Bogor 16680, West Java, INDONESIA \\ ${ }^{2}$ Alumni, Department of Environment Economic, Faculty of Management and Economic, IPB University. Darmaga, Bogor 16680, \\ West Java, INDONESIA \\ *Corresponding author's E-mail: basuki_wasis@yahoo.com
}

\section{ARTICLE HISTORY}

Received: 10 August 2019

Revised received: 29 August 2019

Accepted: 05 September 2019

\section{Keywords}

Damage environment

Economic valuation

Illegal logging

Tropical rain forests

\begin{abstract}
Tropical rain forests in Simalungun Regency, North Sumatra Province, Indonesia have experienced environmental damage due to illegal logging. Illegal logging activities can effect to environmental damage as well as environmental economic losses. This study aimed to analyze soil and environmental damage as well as to assess economic loss of environmental damage due to illegal logging activities in tropical rain forests in Simalungun Regency, North Sumatra Province Indonesia. The method of taking samples and analyzing environmental damage were conducted by purposive sampling. Data from laboratory tests of soil physical, chemical and biological properties were analyzed by statistical tests. The economic valuation method of environmental damage used the Permen LH No. 13 year of 2011, Republic of Indonesian. Illegal logging activities caused environmental damage in tropical rain forests (covering 45.65 ha). Illegal logging had a significant effects toward the bulk density increase, as well as the C-organic decrease. In other hand Illegal logging had a significant effects on sand fraction, total microorganisms, and soil respiration. Based on the environmental economic valuation, the economic loss due to illegal logging on tropical rain forests amounting to IDR $319,799,679,000$ (\$22,842,834.21).
\end{abstract}

(C)2019 Agriculture and Environmental Science Academy

Citation of this article: Wasis, B., Saharjo, B.H., Putra, M.H.W.and Winata, B. (2019). Analysis of enviromental damage and enviromental economic valuation on tropical rain forest destruction in Simalungun Regency, North Sumatera Province, Indonesia. Archives of Agriculture and Environmental Science, 4(3): 313-318, https://dx.doi.org/10.26832/24566632.2019.040309

\section{INTRODUCTION}

Tropical rain forests in the world are in three main parts, namely first in South America (around 400 million ha) centered in the Amazon river valley - Brazil, second in Indonesia - Malaya (around 250 million ha) and in West Africa (180 million ha) valley - Congo River to Guyana Bay (Soerianegara and Indrawan, 2005; Kusmana et al., 2014). Tropical rain forest is a climax ecosystem with megabiodiversity where a half the species of flora and fauna throughout the world live in this forest. Tropical rain forest is also dubbed as "the world's largest pharmacy" because nearly $1 / 4$ of modern medicine derives from plants in tropical rain forest. In other hand, this forest ecosystem has a important role on ecosystem services, such as supporting the hydroorology cylce, absorbing carbon and producing oxygen), storing very high biodiversity (Richards, 1957; Collins et al., 1991; Leksono, 2007; Irwan, 2007; Kusmana et al., 2014). 90\% of the world's medicines come from tropical forests (Wasis et al., 2018b).

Southeast Asia's tropical rain forests have 25-30 thousand species. Indonesia's rainforests are home to thousands of species diversity. So it is not wrong if Indonesia is called Megabiodiversity Country. Indonesia's land covers only $1.3 \%$ of the earth's land mass, but Indonesia has $10 \%$ of the world's plants, $12 \%$ of mammals, $16 \%$ of reptiles and amphibians, $17 \%$ of birds (Collin et al., 1991). Indonesia, has more than 38,000 plant species, $55 \%$ of which are endemic plants. Palm species are also most commonly found in Indonesia with 477 species, of 
which 225 are endemic species. In terms of plant diversity, Indonesia ranks in the top five in the world (Bappenas, 2003). The island of Sumatra has more than 10,000 species of higher plants, most of which grow in lowland forests. In terms of fauna, Sumatra is the richest island in Indonesia, because it has 210 mammal species ( 9 endemic), 580 bird species (19 endemic species), 194 reptilian species, 62 amphibian species, and 272 freshwater fish species (30 endemic species) (Bappenas, 2003). Tropical rain forests have a much greater metabolic activity and ability than forests in sub-tropical, temperate and boreal regions because they get sunshine all year round. However, with high temperatures and rainfall in the tropics causing weathering, decomposition of surface runoff, nutrient leaching and erosion also runs fast / high (Irwan, 2007; Wasis, 2012; Wasis et al., 2012; Siregar et al., 2018).

Tropical rain forests in Simalungun Regency, North Sumatra Province are protected areas because they are in slopes $>90 \%$ and podsol land (Law No. 41 of 1999 Republic of Indonesia concerning Forestry) Protected areas are areas designated with the main function of protecting the environmental preservation which includes natural resources and artificial resources. Environmental damage activities in tropical rain forests in Simaungun Regency are carried out by converting forest land cover to plantations. Environmental damage is done through covering road construction activities (cut and fill), clearing of trees, destroying entire vegetation, skidding, dividing tree trunks, and land clearing. The results of the measurement of forest areas by the North Sumatra Province Forestry Service, that illegal logging activities are indeed located in natural forest areas. The impact of tropical rain forest tree felling activities on environmental damage and environmental losses has not been done much. This study aimed to analyze soil and environmental damage as well as to assess economic loss of environmental damage due to illegal logging activities in tropical rain forests in Simalungun Regency, North Sumatra Province Indonesia.

\section{MATERIALS AND METHODS}

\section{Experimental design}

Field research and laboratory analysis was conducted in AprilJune 2014 in Simalungun Regency, North Sumatra Province, Indonesia. Analysis of land damage and economic valuation of environmental damage is carried out in May - June 2019.

\section{Research materials}

The research material used for land and vegetation comes from protected forest areas that were encroached and logged (damaged) and intact tropical rain forests in Simalungun Regency, North Sumatra Province

\section{Preparation of forest observation plots}

Measurements and observations of potential timber were conducted on 20 meters $\times 20$ meters for trees (hutan hujan tropis) (Kusmana and Istomo, 1995, Laar and Akca, 1997; Soerianegara and Indrawan, 2005). The measurement results were recorded in tally sheets that have been distinguished in each plot size.

\section{Soil sampling}

Soil sampling was done by purposive sampling on tropical rain forest, and damage forest. The study was conducted on three plots on tropical rain forest and damage forest of $20 \mathrm{~m} \times 20 \mathrm{~m}$ (0.04 ha) each. Within the mine, tropical rain forest and damage forest, three subplots of $1 \mathrm{~m} \times 1 \mathrm{~m}$ were placed randomly for ground sampling. Then the soil sample was composited. Soil sampling for the chemical properties and biological properties of soil was taken evenly on the soil surface of 0-20 cm deep. Soil taking was done by composite as much as $1 \mathrm{~kg}$. Soil sampling for soil physical properties was done at ground level of $0-20 \mathrm{~cm}$ depth. Intake of soil was done intactly by using ring sample diameter of $7 \mathrm{~cm}$ with height of $5 \mathrm{~cm}$.

\section{Soil analysis}

The soil taken from the field was analyzed in the laboratory. Soil analysis for physical properties such as bulk density, soil permeability and available water; for chemical properties suh as soil $\mathrm{pH}$, C-organic, nitrogen $(\mathrm{N})$, sand and clay; for biological properties such as total microorganism, total fungi, $\mathrm{P}$ dissolving bacteria and respiration. The location of sample in tropical rain forest and damage forest land wass located side by side, so the difference of soil type, topography, climate and other was relatively assumed same.

\section{Data analysis}

Data of laboratory test of soil physical, chemical properties and biology properties, analyzed by statistical test. Descriptive analysis was done by describing the average value of each variable on three replicates and categorized based on the criterion of soil properties. While for statistical analysis was done by using T-Test at $95 \%$ confidence interval. This procedure was done to determine the impact on soil physical and chemical properties as a result of the forest encroachment. Software used in statistical analysis wass SPS 16.00 (Mattjik and Sumertajaya; 2013; Stell and Torries 1991; Wibisono, 2009). Analysis of soil damage using PP Number 150 of 2000, and economic valuation analysis of environmental damage using guidelines for calculating loss of LH Permen Number 13 of 2011, Republic of Indonesia..

\section{RESULTS AND DISCUSSION}

Environmental damage due to illegal logging in tropical rain forests

\section{General conditions of research location}

Tropical rain forest area in Simalungun Regency, North Sumatra Province is a protected forest area. There were several tree species that be found in this forest ecosystem (tropical rain forest) namely Shorea sp., Ficus sp., Altingea exelsa, Schima wallichii, Manglitia glauca, Dacrydium junghuhnii, etc. with biomass 
of $977.4 \mathrm{~m}^{3}$ / ha or 488.7 tons / ha (Table 1). In other hand, there were no tree species found in degraded land (Table 1). Tropical rainforests had red and yellow podoslik soil types with soil solum (horizon A and horizon B) around $30-60 \mathrm{~cm}$, where the horizon A (top soil) around $10-20 \mathrm{~cm}$. The soil texture in this location was dominated by sandy. The land was very suitable as a water catchment area, but very prone to erosion and flooding. The cutting down of tropical rainforest had caused the death of all tropical rain forest vegetation. The road construction for logging (illegal logging) was disturbing soil layer on the dept of 2$8 \mathrm{~m}$. The using of rock cover (60-100\%) was done to hardening process on this road construction. This condition might cause the forest ecosystem degradation particularly on soil properties. In degraded forest land, the soil erosion consisted of several types, such as : (a). depth of $10-30 \mathrm{~cm}$; width of $10-60 \mathrm{~cm}$; length of $5-20 \mathrm{~m}$, (b). depth of $10-30 \mathrm{~cm}$; width of $10-60 \mathrm{~cm}$; length of $10-20 \mathrm{~m}$, (c). depth of $10-30 \mathrm{~cm}$; width of $10-60 \mathrm{~cm}$; length of $10-30 \mathrm{~m}$. The natural forest logging effected to soil solum loss (about $30-60 \mathrm{~cm}$ ), where the top soil loss was 10 $20 \mathrm{~cm}$. When the rate of soil formation was $25 \mathrm{~cm}$ per 100 years (Hardjowigeno, 2007), so probability for the time needed for soil formation after forest degradation (similar to tropical rain forest soil again) was about 3200 years.

Impacts of tropical rain forest damage were the (1). loss of flora and fauna, (2). reducing oxygen productivity and $\mathrm{CO}_{2}$ absorption, (3). hydrology cycle disruption, (4). causing the catastrophic such as floods, droughts, landslides, erosion, and sedimentation (5). changing in environmental geology including aesthetic conditions, (6). reduction of soil productivity, (7). micro climate change, as well as (8). various socioeconomic problems. Damage to tropical rain forests could not be restored as usual (irreversible). If the carrying capacity of the environment has been exceeded, then the function of the ecosystem will be disrupted and damaged which causes the loss of the environmental economy (Dumairy, 1992; Wasis, 2012, Wasis et al., 2018; Saharjo and Wasis, 2019).

\section{Soil physical properties}

Table 2 showed the effects of illegal logging toward the soil properties in tropical rain forest. Illegal logging significantly effected to the bulk density at $95 \%$ confidence interval. In other hand illegal logging had no significant effect on the permeability and available water. Based on the regulation of Indonesian Government (PP No. 150 / year of 2000 about Soil Damage Control for Biomass Production in Indonesia), it was known that there was an environmental degradation on soil properties especially on bulk density and permeability.

Figure 1 showed the average value of physical properties of soils in tropical rain forests and damaged forests due to illegal logging. Illegal logging in tropical rain forests had a significant effect on bulk density increase. This fact was indicated by the increasing of bulk density parameter between tropical rain forest $\left(1.03 \mathrm{~g} / \mathrm{cm}^{3}\right)$ and damaged forest $\left(1.56 \mathrm{~g} / \mathrm{cm}^{3}\right)$. The increasing of bulk density could effect to the soil permeability and finally to available water in the soil. These fact were supported by the decrease of soil permeability $(61.29 \mathrm{~cm} /$ hour in tropical rain forest to $40.92 \mathrm{~cm} /$ hour in damage forest) as well as the decrease of available water in the soil $(17.49 \%$ in tropical rain forest to $6.29 \%$ in damage forest). These condition indicated that illegal logging in tropical rain forest could disturb the soil characteristics and also the water system in the soil.

Table 1. Biomass in tropical rain forests and damage forest.

\begin{tabular}{lccc}
\hline Cover land & Type of vegetation & Volume (m $\left.{ }^{3} / \mathrm{ha}^{\prime}\right)$ & Biomass (ton/ha) \\
\hline Tropical rain forests & $\begin{array}{c}\text { Shorea sp, Ficus sp. Altingea exelsa, Schima wallichii, } \\
\text { Manglitia glauca, and Dacrydium junghuhnii, etc. }\end{array}$ & 977.4 & 488.7 \\
Damage forest & - & 0 & 0 \\
\hline
\end{tabular}

Table 2. Illegal logging effects on the soil physical properties in tropical rain forest.

\begin{tabular}{lccc}
\hline Physical properties & Tropical rain forests & Damaged forest & Change \\
\hline Bulk Density $\left(\mathrm{g} / \mathrm{cm}^{3}\right)$ & $1.03 \pm 0.09^{*}$ & $1.56 \pm 0.07 \mathrm{~d}$ & $+0.53(51.45 \%)$ \\
Permeability $(\mathrm{cm} /$ hour) & $61.29 \pm 3.28$ & $40.92 \pm 3.12 \mathrm{~d}$ & $-20.37(33.23 \%)$ \\
Available water (\%) & $17.40 \pm 0.73$ & $6.29 \pm 0.99$ & $-11.11(63.80 \%)$ \\
\hline
\end{tabular}

* significant at $95 \%$ confidence interval, .d = damage (PP 150 / 2000).

Table 3. Illegal logging effects on the soil chemical properties in tropical rain forest.

\begin{tabular}{lccc}
\hline Chemical properties & Tropical rain forests & Damaged forest & Change \\
\hline $\mathrm{pH}$ & $5.00 \pm 0.28$ & $4.65 \pm 0.07$ & $+0.35(7.00 \%)$ \\
C-Organic (\%) & $19.63 \pm 1.39^{*}$ & $0.54 \pm 0.03$ & $-19.09(97.25 \%)$ \\
Nitrogen (\%) & $0.71 \pm 0.18$ & $0.01 \pm 0.01$ & $-0.70(98.59 \%)$ \\
Clay (\%) & $25.44 \pm 0.61^{*}$ & $9.29 \pm 0.11 \mathrm{~d}$ & $-16.15(63.48 \%)$ \\
Sand (\%) & $62.51 \pm 9.72$ & $85.31 \pm 1.68 \mathrm{~d}$ & $-22.8(36.47 \%)$ \\
\hline
\end{tabular}

${ }^{*}$ significant at $95 \%$ confidence interval,.$d$ = damage (PP $\left.150 / 2000\right)$. 
Table 4. Illegal logging effects on the soil biological properties in tropical rain forest.

\begin{tabular}{lccc}
\hline Biology properties & Tropical rain forests & Damaged forest & Change \\
\hline Total microorganisms $\left(\times 10^{6} \mathrm{cpu}\right)$ & $10.80 \pm 0.28^{*}$ & $3.10 \pm 0.14$ & $-7.70(71.30 \%)$ \\
Total fungi $\left(\times 10^{4} \mathrm{cpu}\right)$ & $4.05 \pm 0.07^{* *}$ & $0.00 \pm 0.00 \mathrm{~d}$ & $-4.05(100 \%)$ \\
P dissolving bacteria $\left(\times 10^{3} \mathrm{cpu}\right)$ & $1.25 \pm 0.35$ & $0.00 \pm 0.00 \mathrm{~d}$ & $-1.25(100 \%)$ \\
Respiration $\left(\mathrm{mgC}-\mathrm{CO}_{2} / \mathrm{kg}\right.$ soil $/$ day) & $12.45 \pm 0.21^{*}$ & $2.90 \pm 0.71$ & $-9.55(76.71 \%)$ \\
\hline
\end{tabular}

${ }^{*}$ significant at $95 \%$ confidence interval, . ${ }^{* *}$ significant at $95 \%$ confidence interval $d=$ damage (PP $\left.150 / 2000\right)$.



Figure 1. Average value of physical properties of soils in tropical rain forests and damaged forests. Description : BD (Bulk density : $\mathrm{g} / \mathrm{cm} 3, P M$ (Permeability: $\mathrm{cm} /$ hour), AW (Available water :\%).

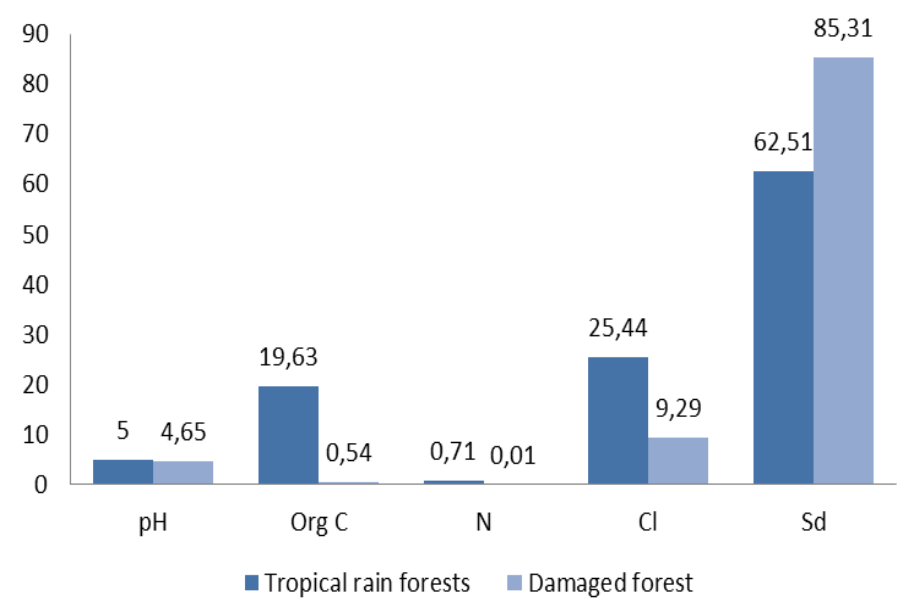

Figure 2. Average value of chemical properties of soils in tropical rain forests and damaged forests. Description : $\mathrm{pH}(\mathrm{pH})$, Organic C (organic C : \%), N (Nitrogen :\%), Cl (Clay:\%); Sd (Sand ;\%).

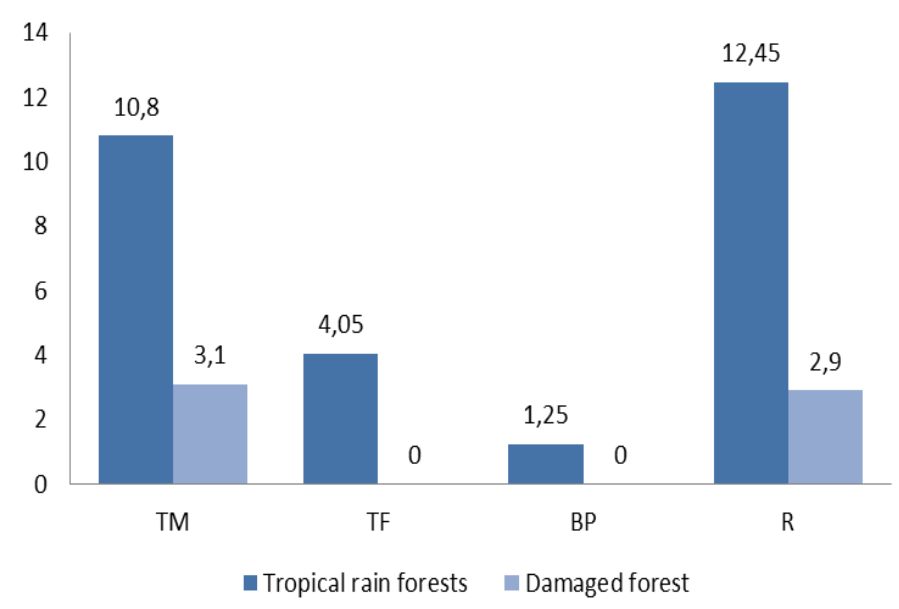

Figure 3. Average value of biology properties of soils in tropical rain forests and damaged forests. Description: TM (total microorganisms: $\times 10^{6} \mathrm{cpu}$ ), TF (total fungi : $\left.\times 10^{4} \mathrm{cpu}\right), \mathrm{BP}\left(P\right.$ dissolving bacteria : $\left.\times 10^{3} \mathrm{cpu}\right)$ and $R$ (respiration: $\mathrm{mgC}-\mathrm{CO}_{2} / \mathrm{kg}$ soil /day).

\section{Soil chemical properties}

Table 3 showed illegal logging effects on the soil chemical properties in tropical rain forest. Illegal logging had a significant effect to the C-organic in the soil and clay parameter. Illegal logging activities had caused a significant decrease in soil organic $\mathrm{C}$ by $19.09 \%$ (97.25\%). Illegal logging activities had caused environmental damage because it exceeded the standard criteria for damage to sand and clay parameters. Illegal logging also had caused damage to the top soil layer. This fact was caused by the low soil organic matter in damaged soil. The loss of vegetation could cause the loss of potential organic matter resources in the forest ecosystem. Soils with organic matter content or with high clay content have a CEC higher than soils with low organic matter content or sandy soil (Hardjowigeno, 2007; Wasis, 2012).

Figure 2 showed that C-organic and $\mathrm{N}$ lelement in the soil in damaged forest were lower than in tropical rain forest soils. That condition might be caused by the loss of vegetation cover and soil solum. The high level of organic matter and nitrogen in natural forest land was sourced from the addition of a network of leaves, stems and roots of natural forest vegetation that dies to the ground surface. The process of harvesting natural forests caused loss of tropical rain forest biomass by $80 \%$. So that logging in natural forests would cause loss of diversity and flora and fauna populations, impoverishing ecosystems and reducing soil fertility. Harvesting of natural forest stands results in environmental damage that was a decrease in the rate of infiltration, increased surface runoff and erosion, and increased loss of organic C, N, K, Ca, and Mg (Soepardi, 1983; Wasis, 2006; Hardjowigeno, 2007; Wasis, 2012).

\section{Soil biological properties}

Illegal logging significantly effected on soil biological properties (Table 4), such as on parameters of total microorganisms and respiration, as well as total fungi. While the parameter of $P$ solvent bacteria was not significantly effected by illegal logging. Based on the regulation of Indonesian Government (PP No. 150 / year of 2000 about Soil Damage Control for Biomass Production in Indonesia), it was known that there was an environmental degradation on soil biological properties especially on total fungi and $\mathrm{P}$ dissolving bacteria.

Figure 3 showed that Illegal logging caused a significant decrease in total microorganisms by $7.70\left(\times 10^{6} \mathrm{cpu}\right)(71.30 \%)$ and respiration by 9.55 ( $\mathrm{mgC}-\mathrm{CO}_{2} / \mathrm{kg}$ soil /day) (76.71\%). Illegal logging activities caused damage to biological and environmental characteristics because it exceeded the standard criteria for damage to the total parameters of fungi and $\mathrm{P}$ solvent bacteria. 
Microorganism played important role on the soil nutrient cycle. Organic matters could be decomposed to the unpretentious element form because of the existence of soil microorganism. This phenomenon could effect to the soil fertility improvement as well as to the growth of plant on the soil. The number of each group of microorganisms could achieved to millions per gram of soil. The number of microorganisms was very useful to determining the place of microorganisms in relation to the root system, residual organic matter, soil profile depth and related to soil fertility (Anas, 1989; Wasis, 2012).

Calculation of environmental economic losses

The calculation of environmental economic loss was analyzed by the Indonesian Government's regulation, namely Permen LH No. 13 year of 2011 concerning Compensation for Losses Due to Pollution and or Environmental Damage. Based on the results of field verification and laboratory analysis, refered to Permen LH No. 13 year of 2011, the calculation of the cost of restoring environmental damage to tropical rain forests due to illegal logging was follows:

\section{Ecological damage}

Cost of activating the water function

The cost of activating the function of the water system was IDR $40,500,000 /$ ha.. Costs needed to turn on the function of the water system on an area of 45.65 ha $=45.65$ ha $\times$ IDR $40,500,000 /$ ha $\times 50$ years $=$ IDR 92,441,250,000.

Water management arrangement

The cost of water management (based on the benefits of water for cultivation) was IDR. 22,810,000/ha. Costs needed for water distribution in an area of $45.65 \mathrm{ha}=45.65 \mathrm{ha} \times$ IDR $22,810,000$ / ha $=$ IDR $1,041,276,500$.

\section{Erosion and runoff control}

The cost of erosion and runoff control due to illegal mining by making terraces and rorak were IDR 6,000,000 ha. Costs needed to control erosion on an area of 45.65 ha $=45.65$ ha $x$ IDR 6,000,000/ha = IDR 273,900,000.

\section{Land formation}

The cost for land formation due to the land destruction wass IDR 500,000/ha. Cost needed for land formation on an area of 45.65 ha $=45.65$ ha $x$ IDR 500,000/ha = IDR 22,825,000.

\section{Nutrient recycling}

The cost of recycling of nutrients lost due to soil destruction wass IDR 4,610,000/ha. Costs needed to recycle nutrient on land area of 45.65 ha $=45.65$ ha $\times$ IDR. $4,610,000 /$ ha $=$ IDR $210,446,500$.

\section{Waste decomposition}

The cost of the waste decomposition fuction which lost due to land damage wass IDR 435,000/ha. Costs needed for the waste decomposition function which lost on an area of 45.65 ha $=$. 45.65 ha $x$ IDR 435,000/ha = IDR 19,857,750g.

\section{Biodiversity}

Illegal logging caused the lost of biodiversity. Because of that, the cost required to restore the biodiversity of IDR 2,700,000/ ha. Cost for biodiversity loss on 45.65 ha of land $=45.65$ ha $x$ IDR. 2,700,000/ha = IDR. 123,255,000.

\section{Genetic resources}

Recovery costs due to loss of genetic resources amounted to IDR 410,000/ha. The cost for the loss genetic resources on $45.65 \mathrm{ha}=45.65 \mathrm{ha} \times \operatorname{IDR} 410,000 / \mathrm{ha}=\operatorname{IDR} 18,716,500$.

\section{Carbon release}

The cost of releasing carbon due to illegal logging was IDR $32,310,000 / \mathrm{ha}$. The cost required for the function of carbon release on an area of 45.65 ha $=45.65$ ha $x$ IDR 32,310,000/ha $=$ IDR $1,474,951.50$

Total ecological damage (a-i) = IDR 95.526.478.750,

\section{Economical losses}

\section{Value of biomass}

Economical loss due to the loss of biomass wass IDR 3,300,000/ $\mathrm{m}^{3}$. Costs required for the function of carbon release in an area of 45.65 ha $=45.65$ ha $=45.65$ ha $\times 977.4 \mathrm{~m} 3 / \mathrm{ha} \times$ IDR. $3,300,000 / \mathrm{m} 3=$ IDR. $147,240,423,000$.-

\section{Disadvantages of environmental economics}

The cost of disadvantages environmental due to illegal logging was IDR $32,310,000 /$ ha/years. In the part of disadvantages environmental, there was $=45.65$ ha $\times$ IDR 32,000,000/ha $\times 50$ years $=$ IDR 73,040,000,000.

Total economic losses (1-2) = IDR 220.280.423.000.

\section{Environmental recovery}

The cost of restoring the environment to activate the lost ecological functions were:

a. Water supply through reservoir construction IDR1.848.825.000

b. Control of runoff and erosion = IDR. 273.900 .000

c. Land formation = IDR. 22.825 .000

d. Nutrient recycling = IDR. 210.446.500

e. Decomposition of waste $=$ IDR 19.857.750

f. Biodiversity = IDR 23.255.000

g. Genetic Resources = IDR 18.716 .500

h. Carbon release $=$ IDR 1.474 .951 .500
Total enviroment recovery $(\mathrm{a}-\mathrm{h})=$ IDR 3.992.777.250

The total cost of damage on tropical rainforest due to illegal logging were the ecological damage + economic loss + environmental recovery, which were IDR 95.526.478.750,- + 
IDR 220.280.423.000,- + IDR 3.992.777.250,- =

IDR

$319.799 .679 .000,-(\$ 22,842,834.21)$

\section{Conclusion}

It is concluded that illegal logging activities had a negative impacts to the environmental degradation in tropical rain forests in Simalungun Regency, North Sumatra Province covering an area of $45.65 \mathrm{ha}$. The negative impacts included the ecological dan economical aspects. Illegal logging significantly effect to the bulk density increase. In other hand, illegal logging also significantly to the decrease of C-organic, sand fraction, total microorganisms, total fungi and respiration. Environmental economic valuation due to illegal logging of tropical rain forests amounting to IDR $319,799,679,000$ (\$22,842,834.21).

Open Access: This is an open access article published under the terms and conditions of Creative Commons AttributionNonCommercial 4.0 International License which permits noncommercial use, distribution, and reproduction in any medium, provided the original author(s) if the sources are credited.

\section{REFERENCES}

Adamowicz, V. and Boxall, P. (2001). Future Directions of Stated Choice Methods for EnvironmentValuation. Vic Adamowicz and Peter Boxall. Choice Experiments: A New Approach to Environmental Valuation, April 10, 2001. London, England.

Anas, I. (1989). Petunjuk Laboratorium: Biologi Tanah dalam Praktek. Bogor: Departemen Pendidikan dan Kebudayaan. Pusat Antar Universitas Bioteknologi. Institut Pertanian Bogor.

Bapenas (2003). Indonesian Biodiversity Strategy and Action Plan 2003-2010 (Strategi dan Rencana Aksi Keanekaragaman Hayati Indonesia 2003-2020). IBSAP Dokumen Regional. Pemerintah Republik Indonesia.

Binkley, D. (1987). Forest Nutrition Management. Duke University, Durham, North Carolina. USA.

Collins, N.M., Sayer, J.A. and Whitmore, T.C. (1991). The Conservation Atlas of Tropical Forests. Asia and The Pacific. Macmillian Press Ltd; London.

Dumairy (1992). Ekonomika Sumberdaya Air: Pengantar ke Hidronomika. BPFE Yogyakarta pp. 222.

Fauzi, A. (2014). Valuasi Ekonomi dan Penilaian Kerusakan Sumberdaya Alam dan Lingkungan. PT Penerbit IPB Press, pp. 246.

Foth, H. D. (1994). Dasar-dasar Ilmu Tanah. PT Erlangga. Jakarta.
Hardjowigeno S. (2007). IImu Tanah. Akademika Pressindo. Jakarta.

Irwan, Z.D. (2007). Prinsip-prinsip Ekologi, Ekosistem, Lingkungan dan Pelestariannya. Penerbit Bumi Aksara Jakarta. pp. 210.

Kusmana, C. and Istomo (1995). Forest Ekology. Faculty of Forestry IPB, Bogor. pp. 190.

Kusmana, C., Setiadi, Y., Hilwan, I., Istomo, Rusdiana, O., Wasis, B., and Mulyana, D. (2014). Forest Ekology. Materi Kuliah Bagian Ekologi Hutan Departemen Silvikultur, Fakultas Kehutanan IPB University. Indonesia.

Laar, A.V. and Akca, A. (1997). Forest Mensuration. Cuvillier Verlag Gotingen. pp. 418.

Leksono, A.S. (2007). Ekologi Pendekatan Deskriptif dan Kuantitatif. Bayumedia Publishing. pp. 209.

Lutz, H.J. and Chandler, R.F. (1965). Forest Soil. John Wiley \& Sons, Inc. New York. Mattjik, A.A. and Sumertajaya, I.M. (2013). Experimental Design with SAS Applications and Minitab. IPB Press. Bogor.

Saharjo, B.H. and Wasis, B. (2019). Economic Valution on Enviromental Damage due Peat Fire in Mak Teduh Village Riau Province. Jurnal Silvikultur Tropika, 10 (01): 63-67.

Siregar, Y.F., Wasis, B. and Hilwan, I. (2018). Carbon stock potential of Narundong Forest KPH Region VI North Sumatera. Indonesian Journal of Agricultural Science (JIPI), 23(1): 67-73.

Soepardi, G. (1983). Sifat dan Ciri Tanah. Jurusan Ilmu Tanah Fakultas Pertanian IPB. Bogor.

Soerianegara, I. and Indrawan, A. (2005). Indonesian Forest Ecology. Department of Forest Management, Faculty of Forestry IPB, Bogor.

Stell, R.G.D. and Torries, J.H. (1991). Statistical Principles and Procedures, A Biometric Approach. PT Gramedia Pustaka Utama Jakarta, pp. 149-167.

Tan, K.H. (1995). Enviromental Soil Science. Marcel Dekkker Inc. New York. pp. 255.

Vranken L., Turnhout, P.V., Eeckhaut, M.V.D., Vandekerckhove, L. and Poesen, J. (2013). Economic valuation of landslide damage in hilly regions: A case study from Flanders. Belgium. Science of the Total Environment, 447: 323-336

Wasis, B. (2006). Comporison of site quality between first rotation and second rotation Acacia mangiumplantation forest (A Case study in Industrial plantation forest of PT Musi Hutan Persada, South Sumatra Province). Dissertation: Bogor Agricultural University (IPB). Bogor.

Wasis, B. (2012). Soil properties in natural forest destruction and conversion to agricultural land in Gunung Leuser National Park, North Sumatera Province. Journal of Tropical Forest Management (JMHT), XVIII (3): 206-212.

Wasis, B., Arifin and Winata, B. (2018b). Impact of bauxite mine to natural forest biomass and soil properties in Kas Island, Riau Island Province in Indonesia. Archives of Agriculture and Environmental Science, 3(3): 264-269.

Wasis, B., Saharjo, B.H., Kusumadewi, F., Utami, N.H., and Putra, M.H.W. (2018a). Analysis of economic valuation of environmental damage due to sand mine in Gumulung Tonggoh, Cirebon District, West Java Province, Indonesia. Archives of Agriculture and Environmental Science, 3(4): 360-366.

Wasis, B., Setiadi, Y. and Purwanto, E. (2012). Perbandingan Sifat Kimia Tanah dan Biologi Tanah akibat Keterbukaan Lahan pada Hutan Reboisasi Pinus di Kecamatan Pollung Kabupaten Humbang Hasudutan, Sumatera Utara. Jurnal Silvikultur Tropika, 03(01): 33-36.

Wibisono, Y. (2009). Metoda Statistik. Method. Gadjah Mada University Press. Yokyakarta. pp. 529-603. 